\title{
Yeasts from Antarctica
}

\author{
By MARGARET E. DI MENNA \\ Soil Bureau, Department of Scientific and Industrial Research, \\ Wellington, Nerw Zealand
}

(Received 12 April 1960)

\section{SUMMARY}

The yeast flora of moss from Granite Harbour and of soils from Wright Dry Valley in the McMurdo Sound region of Antarctica was examined. There were 75,000 yeasts/g. on the moss; species recovered were Cryptococcus laurentii, C. albidus and Rhodotorula minuta. Yeasts were isolated from 8 of the 12 soil samples in numbers up to $5000 / \mathrm{g}$. Strains of Candida scottii, whose maximum growth temperature was $c .15^{\circ}$, were the predominant soil yeasts.

\section{INTRODUCTION}

The soils of Antarctica are characteristically very cold and dry. Although some have recognizable pedological features (personal communication from J. D. McCraw), all have a primitive organic cycle, for the terrestrial photosynthesizing vegetation of the continent is virtually limited to algae, mosses and lichens. Because of the climatically extreme conditions and the sparse macro-flora and -fauna, the microbiology of Antarctic soils is peculiarly interesting. The following is an account of yeasts recovered from soils and moss collected in the region of McMurdo Sound.

\section{MATERIALS}

In February 1957 some moss (Bryum antarcticum) with sand adhering to it was collected from a rock crevice $20 \mathrm{ft}$. above tide level at Granite Harbour, McMurdo Sound. It was sent to New Zealand by air and reached the laboratory 7 days after collection. The sample weighed $c .500 \mathrm{~g}$. and its $\mathrm{pH}$ value was 6.5 .

Seven samples of soil containing algae (No. 474, 476, 478, 479, 482, 483, 487) were collected from Wright Dry Valley, McMurdo Sound, in January 1958. They were taken with sterile precautions and kept in deep freeze until they reached the laboratory.

Five other soil samples were collected in January 1959, also in Wright Dry Valley. Their descriptions are as follows: (1) Wet granite sand at edges of pools east of Lake Vanda; pH 8.0. (2) Encrustation from depression on floor of North Arm, Wright Dry Valley; pH 8.5. (3) 'Loess'-like sand from granite basement between dolerite dyke swarms; pH 8.2. (4) Sand from centre of a damp depression, the upper layer appearing to have an organic component; $\mathrm{pH} 8 \cdot 0$. (5) Sand from a damp depression, basement granite with dolerite dykes, organic debris on surface; $\mathrm{pH} 8 \cdot 1$. These samples were also taken with sterile precautions and kept refrigerated. 


\section{METHODS}

The moss sample was cultured on acidified glucose peptone agar plates (glucose, $4 \%, \mathrm{w} / \mathrm{v}$; peptone, $1 \%, \mathrm{w} / \mathrm{v}$; agar, $2 \%, \mathrm{w} / \mathrm{v}$; brought to $\mathrm{pH} 4-4.5$ by the addition of $10 \%(\mathrm{v} / \mathrm{v}) \mathrm{HCl}$ solution to the molten medium immediately before the plates were poured; the solidified plates were dried in an oven at $c .70^{\circ}$ before inoculation so that the water in the inoculum would be absorbed). Ten g. moss were diluted serially with sterile tapwater to $1 / 25,1 / 250,1 / 1000$ and $1 / 10,000$. Inocula of $0.5 \mathrm{ml}$. were spread on the surfaces of the plates and 6 plates inoculated from each dilution. Four plates/dilution were incubated at room temperature and two at $4^{\circ}$.

Three of the seven 1958 soil samples (No. 474, 482, 487) were cultured on acidified glucose peptone agar. As the samples were small, dilutions were made from amounts varying between $1 \cdot 8$ and $3 \cdot 5 \mathrm{~g}$. to $1 / 100,1 / 1000$ and 1/10,000. Five plates were inoculated from each dilution; three plates/dilution were incubated at room temperature and two at $4^{\circ}$.

The five 1959 soil samples were cultured on acidified glucose peptone agar and on aureomycin + glucose peptone agar $(100 \mathrm{mg}$. aureomycin/l. glucose peptone agar. Dilutions were made from $10 \mathrm{~g}$. soil to $1 / 10,1 / 100$ and 1/1000. Eight plates of acidified glucose peptone agar and four plates of aureomycin + glucose peptone agar were inoculated from each dilution of each sample. In addition, $1 \mathrm{ml}$. of each dilution of the five samples was inoculated into two flasks each containing $100 \mathrm{ml}$. of nitrogen-depleted broth (glucose, 5 g.; $\mathrm{KH}_{2} \mathrm{PO}_{4}, 1 \cdot 0$ g.; $\mathrm{MgSO}_{4} .7 \mathrm{H}_{2} \mathrm{O}, 0 \cdot 5$ g.; Difco Bacto yeast extract, $0 \cdot 1 \mathrm{~g}$.; double glass-distilled water, 1 l.). Half of these cultures (four acidified glucose peptone agar plates, two aureomycin + glucose peptone agar plates, one flask nitrogen-depleted broth for each dilution of each sample) were incubated at room temperature and half at $4^{\circ}$.

Cultures held at room temperature were incubated for 3-7 days before counts were made and subcultures taken. The moss cultures held at $4^{\circ}$ were incubated for 11 days, the 1958 soil cultures for 4 weeks and the 1959 soil cultures for 6 weeks. Both sets of cultures in nitrogen-depleted broth (those at room temperature and those at $4^{\circ}$ ) were subcultured after 6 weeks incubation. Two pour plates were made from each flask ( $1 \mathrm{ml}$. inoculum/plate), one with the nitrogen auxanographic solid medium of Lodder \& Kreger-van Rij (1952, p. 26), one with the same medium + one drop $0 \cdot 1 \%(\mathrm{w} / \mathrm{v})$ yeast extract/plate. Plates inoculated from flasks incubated at room temperature were incubated at room temperature; those from flasks incubated at $4^{\circ}$ were incubated at $4^{\circ}$. Colonies were picked from the room temperature plates after incubation for 3 weeks, and from the $4^{\circ}$ plates after 7 weeks.

\section{RESULTS}

The temperature of incubation did not affect the numbers and species patterns of yeasts isolated from the moss sample. The room temperature cultures indicated that there was a population of 75,000 yeasts/g. wet weight, the $4^{\circ}$ cultures one of 70,000 . Fifty isolates were subcultured from the room temperature cultures; $72 \%$ were Cryptococcus albidus (Saito) Skinner, $20 \%$ C. laurentii (Kufferath) Skinner, and $8 \%$ Rhodotorula minuta (Saito) Harrison. Forty-five isolates were subcultured from the $4^{\circ}$ cultures; all of these grew at least as readily at room temperature as at $4^{\circ} ; 75 \%$ were $C$. albidus, $18 \%$ C. laurentii and $7 \% R$. minuta. 
There was no yeast growth at room temperature on the glucose peptone agar cultures of the 1958 soil samples 474,482 and 487 ; at $4^{\circ}$ there was growth of yeasts on the cultures of soil 487 at the rate of 5000 yeasts/g. wet weight, but no growth on cultures of 474 and 482 .

All seven of the 1958 soils had been cultured for streptomyces in a non-quantitative manner on casein agar (Vernon, 1958) and incubated at $4^{\circ}$. No streptomyces appeared but there was yeast growth on plates inoculated with soils 474, 476, 478 and 487. Presumably yeasts occurred in soil 474 at a rate of less than $100 / \mathrm{g}$., the lowest number that the quantitative glucose peptone agar cultures would detect. Fifty yeasts were subcultured from the glucose peptone agar cultures of soil $\mathbf{4 8 7}$ and eleven from the casein agar. Eleven yeasts were recovered from the casein agar cultures of soil 474, two from 476 and ten from 478. All but three of these isolates were obligatory psychrophilic strains of Candida scottii Diddens \& Lodder. One of the two isolates from soil $\mathbf{4 7 6}$ was a strain of Rhodotorula mucilaginosa (Jorg.) Harrison which grew well at room temperature. Two of the isolates from soil 487, one recovered from glucose peptone agar and one from casein agar, resembled C. scottii except that they could not use potassium nitrate as a nitrogen source.

The yeasts isolated from the five 1959 soil samples cultured on solid media are shown in Table 1. No yeasts were isolated from soil 2 and numbers in the other soils were low. Using the counts from the acidified glucose peptone agar plates incubated at $4^{\circ}$ as a basis for calculation, there were 20 yeasts/g. in soil 1,40 in soil 4 and 30 in soil 5. Yeasts were isolated from soil 3, but the only colony found on the acidified glucose peptone agar plates was on a plate inoculated from the 1/1000 dilution. Psychrophilic Candida scottii was present in soils 1, 4 and 5 together with a number of Cryptococcus and Rhodotorula spp. Sporobolomyces odorus Derx and Cryptococcus spp. were isolated from soil 3.

Moulds were present in some of the samples examined; they grew more vigorously on plates incubated at room temperature than at $4^{\circ}$. There were 450,000 mould colonies/g. moss on plates held at room temperature; yeasts on these plates were counted and subcultured earlier than was desirable because of the spreading habit of the moulds. On moss plates at $4^{\circ}$ the relative growth rate of the yeasts was greater than that of moulds, which at this temperature had restricted, submerged colonies. There were no moulds in the 1958 soils 474 and 487 , but $1600 / g$. in soil 482 . In the 1959 soils, using the counts on aureomycin + glucose peptone agar at room temperature, there were 15 moulds/g. in soil 1 , none in soil 2,20 in soil 3,10 in soil 4 and 20 in soil 5.

Growth in nitrogen-depleted broth subcultured into auxanographic agar was largely of yeasts and moulds; bacterial colonies were only occasional. There were many small yeast and mould colonies in plates from nitrogen-depleted broth flasks inoculated with $1 / 10$ dilutions of soils 1,4 and 5 , and with 1/100 dilutions of soils 4 and 5, but only a few colonies on other plates. Addition of yeast extract to the auxanographic agar made no apparent difference in amount and nature of growth. The following yeasts were recovered from nitrogen-depleted broth at room temperature: Cryptococcus albidus from soils 1, 3, 4 and 5; C. diffluens (Zach) Lodder \& Kreger-van Rij from soil 1; Rhodotorula glutinis (Fres.) Harrison from soils 1 and 2; R. mucilaginosa from soil 2 ; a non-fermenting Torulopsis $\mathrm{sp}$. from soil 2 . The yeasts recovered from nitrogen-depleted broth at $4^{\circ}$ were: $C$. luteolus (Saito) Skinner from 
soil 5; Candida scottii from soils 4 and $5 ; R$. glutinis from soils 3 and $4 ; R$. texensis Mrak, Phaff \& Williams from soils 1, 2 and 5; a cream, fluid, psychrophilic yeast, which resembled $C$. scottii but which could not be freed from a contaminant mould for identification, from soil 1.

Table 1. Yeasts isolated on acidified glucose peptone agar $(\mathrm{pH} 4 \mathrm{GPA})$ and on aureomycin +glucose peptone agar (aureomycin GPA) from five soils from Wright Dry Valley, McMurdo Sound. No yeasts were recovered from soil 2

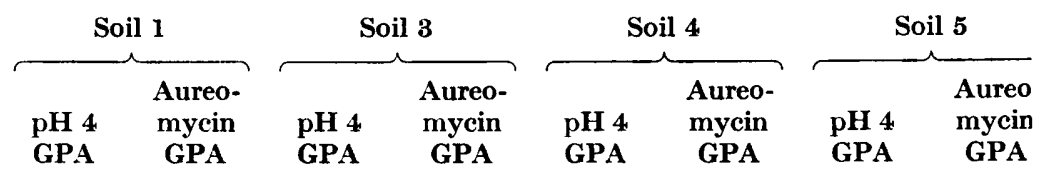

Numbers of isolates at room temperature

\section{Sporobolomyces odorus}

Cryptococcus laurentii

C. albidus

C. luteolus

C. diffluens

Candida scottii

Rhodotorula minuta

R. graminis di Menna

Total number of isolates

Numbers of isolates at $4^{\circ}$

Sporobolomyces odorus

Cryptococcus laurentii

C. diffluens

Candida scottii

Rhodotorula minuta

Total number of isolates

$\cdot$
i
.
.
i
2

$\cdot$
$\dot{1}$
$\cdot$
$\cdot$
$\cdot$
1

$\begin{array}{ll}1 & 1 \\ 1 & \cdot \\ 1 & : \\ . & : \\ . & : \\ . & : \\ . & \cdot \\ 3 & 1\end{array}$

.
$\dot{.}$
$\dot{.}$
$\dot{.}$
$\dot{0}$

$\mathbf{1}$
$\dot{ }$
$\dot{1}$
$\dot{.}$
$\dot{2}$

$\begin{array}{ll}\dot{1} & \text { 1 } \\ \dot{1} & \dot{ } \\ \dot{1} & \dot{2} \\ \dot{1} & \dot{2} \\ \dot{2} & \text {. } \\ \mathbf{2} & \mathbf{3}\end{array}$

$\begin{array}{ll}\dot{2} & \dot{1} \\ \dot{1} & \dot{ } \\ \mathbf{1} & \dot{1} \\ \mathbf{4} & \mathbf{1}\end{array}$

\section{Characteristics of Candida scottii isolates}

As all strains of Candida scottii isolated were obligate psychrophils, their identification presented some difficulties. Representative cultures on glucose peptone agar slopes were incubated at various temperatures. Growth was apparent in 4 days at $0^{\circ}$ and appeared to be as rapid at $4^{\circ}$ as at $10^{\circ}$. At $15-16^{\circ}$ half of the 18 isolates used showed no growth after 10 days, and in the other half growth was scant, dull and wrinkled, not copious and mucoid to fluid as at lower temperatures. Cultures held at $20^{\circ}$ for 10 days showed no growth but remained viable. Cultures held at room temperature for 20 days in winter showed poor growth of the same type seen in cultures at $15^{\circ}$. Ability to produce limited growth at room temperature in winter explains the presence of two isolates of $C$. scottii in room temperature cultures of soil 5 (Table 1). Although the 1959 soils were collected in January they did not reach the laboratory until May. Both the above isolates grew well at $4^{\circ}$. All subcultures used in identification were incubated at $4^{\circ}$ and held for at least 4 times the period used at room temperature; i.e. liquid auxanograms (solid auxanograms were usually unsatisfactory) were kept for 3 months. Apart from the lower maximum temperature for growth, the Antarctic isolates of $C$. scottii resembled those described by Lodder \& Kreger-van Rij (1952, p. 573). Pseudomycelium was well developed; there was no fermentation; glucose, sucrose, maltose, and galactose were used, but 
not lactose; potassium nitrate was used as a nitrogen source. In addition to these diagnostic characters, these isolates of $C$. scottii liquefied gelatin within 10 days and were able to grow in a vitamin-free medium.

\section{DISCUSSION}

If the Antarctic moss with sand adhering to it be regarded as a combination of non-woody plant and soil, the yeasts recovered from it are similar to those found in comparable material in New Zealand. Yeasts from a turf of New Zealand pasture are usually, in the soil, a nitrate-using Cryptococcus sp. such as C. albidus and, on the leaves of the pasture plants, C. laurentii and Rhodotorula spp. (di Menna, 1958, $1959 a)$.

Candida scottii, which appears to be the predominant yeast in those soils of the Wright Dry Valley which contain organic matter, shows adaptation to habitat. Although the strains studied by Lodder \& Kreger-van Rij (1952) would grow at $\mathbf{2 2}^{\circ}$, some of them grew only poorly, so it seems that Antarctic conditions have selected the more psychrophilic strains of a thermophobe species. C. scottii is the predictable yeast species to be found in this ecological niche, for it was first isolated by Scott (1936) from chilled beef, and it has the characteristics of a typical soil yeast, being colourless, mucoid, non-fermenting, nitrate-using, and independent of external sources of growth factors (di Menna, 1958).

Although some of the isolates of Cryptococcus and Rhodotorula spp. recovered from the soil samples, particularly those which occurred on plates inoculated from the higher dilutions, may have been laboratory contaminants, the presence of members of these genera in the moss sample shows that they can indeed be Antarctic inhabitants.

It was not thought that any of the yeasts recovered from nitrogen-depleted broth cultures were capable of fixing atmospheric nitrogen, for yeasts can grow in media with high C:N ratios (di Menna, 1959 b). Some isolates of Candida scottii, inoculated in nitrogen auxanographic liquid media, were left in a refrigerator containing stock cultures on various media. After 5 months, growth in the negative control tubes (basal medium containing glucose, $\mathrm{KH}_{2} \mathrm{PO}_{4}, \mathrm{MgSO}_{4}, \mathrm{CaCl}_{2}, \mathrm{NaCl}$, growth factors) was as heavy as in the positive controls (same basal medium $+\left(\mathrm{NH}_{4}\right)_{2} \mathrm{SO}_{4}$ ) or in the tubes of basal medium $+\mathrm{KNO}_{3}$. The same isolates were again cultured in nitrogen auxanographic liquid medium and incubated for 5 months, but in a refrigerator which contained no other cultures. There was then no growth in the negative controls. Presumably, during the long incubation period, traces of gaseous nitrogenous compounds produced by the stock cultures in the first refrigerator had contaminated the negative control tubes. The amount of growth in plates from nitrogendepleted broth cultures probably indicates the relative amounts of nitrogenous material in the five 1959 soils, and suggests that there was more nitrogen in soils 1 , 4 and 5 than in soils 2 and 3, and ten times more nitrogen in soils 4 and 5 than in soil 1.

Cultures of Canclida scottii, AL25, isolated from soil 487, have been deposited at the Centraalbureau voor Schimmelcultures, Yeast Division, Delft, Netherlands, and at the Brewing Industry Research Foundation, Nutfield, Surrey, England. 
My thanks are due to Mr R. Barwick, formerly of the Department of Zoology, Victoria University of Wellington, who collected the 1957 and 1959 samples; to Mr A. Packard, formerly of the Department of Zoology, University of Auckland, who collected the 1958 samples, and to Dr T. R. Vernon, Plant Diseases Division, Department of Scientific and Industrial Research, Auckland, for his casein agar cultures of the 1958 samples.

This paper is Soil Bureau Publication No. 218.

\section{REFERENCES}

Lodder, J. \& Kreger-van RiJ, N. J. W. (1952). The Yeasts. A Taxonomic Study. Amsterdam: North Holland Publishing Co.

Menna, M. E. Di (1958). Biological studies of some tussock grassland soils. 3. Yeasts. N.Z. J. agric. Res. 1, 939.

Menna, M. E. DI (1959a). Yeasts from the leaves of pasture plants. N.Z. J. agric. Res. 2, 394.

Menna, M. E. DI (1959b). Some physiological characters of yeasts from soils and allied habitats. J. gen. Microbiol. $20,13$.

ScOTT, W. J. (1936). The growth of micro-organisms on ox muscle. I. The influence of water content of substrate on rate of growth at $-1^{\circ} \mathrm{C}$. Coun. sci. industr. Res. Aust. 9, 177.

Vernon, T. R. (1958). Biological studies of some tussock grassland soils. 8. Streptomycetes. N.Z. J. agric. Res. 1, 985. 